\section{EMBL rescue package keeps bioinformatics centre running}

Munich

The threat to the European Bioinformatics Institute (EBI) arising from the European Commission's refusal to fund its running costs seems to have been temporarily lifted.

At a meeting of the council of the European Molecular Biology Laboratory (EMBL) in Heidelberg last week, delegates of EMBL's 16 member states agreed in principle to make up the shortfall of 5 million euros (US $\$ 5$ million) for next year. EBI, based near Cambridge in the United Kingdom, is an outstation of EMBL.

Although EBI scientists are relieved, they have not relaxed completely. Some member states were unable to pledge money immediately, as their research budgets for next year are already fixed, and they will have to make the case for funds to be redistributed. A final decision awaits a special meeting of the EMBL council in March.

Britain will advance money if needed for the first three months of next year to keep EBI fully functioning. Britain is by far the biggest user of the institute, with the number of accesses each month averaging almost twice that of the next most frequent users - the United States and Germany. It is also a strong supporter of EBI's further development.

"This is a vote of confidence for EBI," says Graham Cameron, the institute's joint director. "But we are not out of the woods yet." Although relieved that immediate rescue funds have been found, Cameron stresses a widely held view that "EBI's budget needs to double if it is to become a competitive global force in bioinformatics".

The National Center for Biotechnology Information, the institute's US equivalent, has well over twice its budget. Cameron fears that bioinformaticists, in heavy demand from industry as well as academia, will leave EBI if its prospects do not brighten soon.

Julio Celis, chairman of the EMBL council and head of the Danish Centre for Human Genome Research in Aarhus, shares this concern. "The council meeting last week recognized the importance of bioinformatics as central to many areas of biological and medical research in the next millennium".

He points out that, while confident that member states will come up with the money at the March meeting, "this will only restore EBI's budget to its current level". The council, he adds, will have to be prepared to step up a gear in financing the next EMBL research plan, which starts in 2001.

EBI's success is reflected in its number of accesses, which is rising by 20 per cent per month. The institute expects this to reach 25 per cent, and stay there, by the time the first

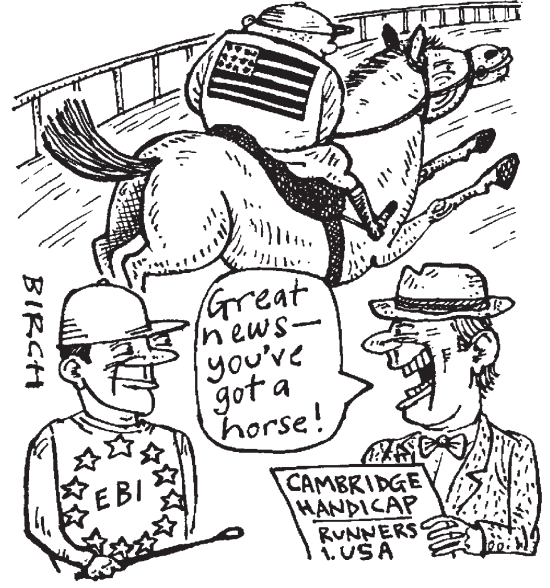

draft of the human genome sequence is completed in the spring.

Bioinformatics is a huge growth area, and Europe must handle the fact that an entirely different level of stable funding must be made available, says Celis.

The new research commissioner, Philippe Busquin, is sympathetic to this view, but says that there is no way around the rules of the European Union's fifth Framework Programme (FP5). These allow funding for research projects, but not for the facilities themselves, although some scientists argue that the rules can be interpreted as allowing core support (see Nature 402, 3 \& 4; 1999).

Busquin believes that both EBI and the European Mouse Mutant Archive (EMMA), a facility based near Rome that has also been thrown into crisis by withdrawal of European funds, must be funded at a European level. But neither can wait until new rules are designed for FP6, which should start in 2003.

At an informal meeting of the council of European research ministers, Busquin will launch a debate on infrastructure funding. He hopes to prompt member states to draw up agreements to finance EBI, EMMA and similar facilities, and to build a consensus for infrastructure funding in FP6.

A spokesman for the research commission points out that member states found a solution for EBI, "though not an ideal one". Member states that voted against core funding of all infrastructure in FP5 may be more discriminating in FP6, he notes.

"It is somewhat ironic that there is so much unallocated money in the FP5 infrastructure pot yet, to solve the EBI crisis, EMBL has to persuade 16 different governments to divert money earmarked for other national purposes, at short notice," says Glauco Tocchini Valentini, director of the CNR Institute of Cell Biology at Monterotondo and a member of EMBL council.

Alison Abbott

\section{Centralized German research centres will compete for funds}

\section{Munich}

Germany's national research centres have agreed to abandon their independence and accept a plan to centralize decisionmaking on strategic research priorities, a move that will increase both competition and collaboration between them.

The plan was announced last week at the annual assembly of the Hermann von Helmholtz Association (HGF), the umbrella group for the 16 centres. Of their DM3 billion (US\$1.6 billion) annual budget, 90 per cent is provided by the federal government, with the remainder coming from Länder (state) governments.

Six strategic 'cornerstones' have been chosen for the institutes' research programmes: the structure of matter, environmental and Earth sciences, transport and space research, health, energy, and enabling technologies.

Each cornerstone is subdivided into several areas. Health, for example, covers biomedical research, medical technologies and public health research. Biomedical research includes areas such as cell-cell and virus-cell interaction, functional genome and proteome analysis by DNA and protein chip technology, gene therapy and bioinformatics.

The first national research centres were set up in the 1950s to carry out nuclear research. Changing political and technological priorities mean that their focus has shifted to medical and environmental research, but recently their research activities have been criticized for a lack of scientific coherence.

The plan will be overseen by a commission of representatives of the institutes and of the federal and regional governments. Under the proposed reorganization, the HGF's senate would act as a supervisory and decision-making board with broad responsibilities for determining strategic research priorities, and allocating money accordingly.

The influential board will comprise members of the HGF, the federal government and the Länder, and also representatives from industry and the heads of Germany's major research organizations - the Max Planck Society, the Fraunhofer Society and the Conference of University Rectors.

The centres would report to - and be financed by - a body responsible for the general direction of their research, and will have to compete for research funds. All proposals will be reviewed by panels of external experts chosen by the senate. 
The groundwork for the shift was laid two years ago, when the centres agreed to divert five per cent of their budgets to a central, DM150-million strategy fund, to which they have to apply competitively (see Nature 387, 837; 1997). “The strategy fund has prepared the ground for more collaboration and competition between the centres," says Detlev Ganten, scientific director of the Max Delbrück Centre for Molecular Medicine in Berlin and head of the HGF. "But now we will have a de facto global budget."

Most HGF members welcome the changes, hoping that they will sharpen the centres' scientific profiles at a time when the Wissenschaftsrat, Germany's science council, has begun a systematic evaluation of the HGF. "Provided that basic research is not excessively damaged, it is certainly the right development," says Hans-Günter Afting, director of the National Research Centre for Environment and Health in Munich.

But some of the HGF's research may have to find a new home. The Bonnbased National Research Centre for Information Technology, for example, will leave the HGF in 2001 and join the Fraunhofer Society, Germany's organization for applied research. According to Ganten, a further reduction of the number of national research centres is "within the bounds of possibility".

Quirin Schiermeier

\section{Nuclear safety and biotech boosted in Japan's budget}

Tokyo

Biotechnology, venture businesses and nuclear safety all receive extra support in Japan's latest supplementary budget, approved by the parliament last week, which is aimed at putting the nation's economy on a full recovery track.

As well as a strong emphasis on public works projects, the supplementary budget — the second this year — includes generous support for science. This is largely a result of prime minister Keizo Obuchi's Millennium Project, which seeks to promote new industries in areas such as biotechnology, information sciences and environmental technology (see Nature 401, 313; 1999).

The supplementary budget totals $¥ 6.79$ trillion (US\$66 billion), of which $¥ 907.6$ billion is earmarked for science and technology, and $¥ 773$ billion for supporting small and medium-sized businesses.

The Science and Technology Agency (STA) will receive $¥ 16.4$ billion for life sciences, including $¥ 4.3$ billion for nuclear magnetic resonance facilities being built at the new headquarters of the Genomic Sciences Centre, ¥1.2 billion for proteomics research, and $¥ 2.4$ billion for the analysis of human complementary DNA (cDNA). The agency will also receive $¥ 46.1$ billion for additional efforts in nuclear safety, following the accident at a uranium-processing plant in Tokaimura, Ibaraki Prefecture.

The Ministry of International Trade and Industry (MITI), which takes over some of the nuclear safety responsibilities of the STA in 2001, and the Ministry of Health and Welfare will receive $¥ 30.8$ billion and $¥ 11.6$ billion, respectively, for nuclear safety research.

MITI will receive $¥ 12.5$ billion for biotechnology-related research, including proteomics projects, while $¥ 35.6$ billion will support venture businesses, particularly entrepreneurial activities at universities.

A budget boost for the Ministry of Agriculture, Forestry and Fisheries will speed up the rice genome sequencing project by almost four years (see Nature 401, 102; 1999).

Public works projects include building at national universities, such as the new campus at Kyoto University. They also include plans for new life-sciences-related research institutes.

The budget brings Japan's science spending beyond $¥ 17$ trillion, as promised by the Science and Technology Basic Plan, which pledged to double science spending between 1996 and 2000.

\section{Wellcome Trust backs Rutherford to host synchrotron}

London

Britain's Wellcome Trust has declared its preference that a new Anglo-French synchrotron source should be built at the Rutherford Appleton Laboratory (RAL) in Oxfordshire. The trust is providing a substantial proportion of the construction costs.

But the statement coincides with an announcement by the UK government that the long-awaited decision over a home for the facility, known as Diamond, will be delayed again to allow two new reports on the candidate sites to be commissioned.

Trade and industry secretary Stephen Byers also said last week that he has asked John Taylor, the director-general of research councils, to seek the views of synchrotron users "on what they see as the key issues of relevance to a decision on the site".

An engineering survey and report are also being commissioned from consultants for the two potential sites - at RAL and at Daresbury Laboratory near Manchester. A decision is now expected in mid-January.

Science minister Lord Sainsbury acknowledged in a letter to the Financial

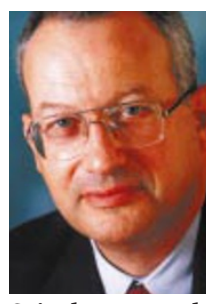

Times newspaper this week that there were "difficult scientific considerations to resolve" about the synergy between the synchrotron and the existing neutron spallation source at RAL, "as well as issues concernSainsbury: tough ing the suitability of the questions over two sites".

science synergy. In its statement last week, the Wellcome Trust says it prefers RAL because it believes that greater scientific benefits would result from a location close to the existing neutron source and to Medical Research Council units and the University of Oxford.

But union officials and some senior synchrotron scientists say this factor is a "small but not overriding consideration", given the small numbers of scientists that would benefit. The trust has also generated anger among supporters of Daresbury by suggesting there are greater planning risks associated with the northern site.

Chris Brough, assistant director of plan- ning for the area, criticizes "unsubstantiated assertions" by the trust's planning consultants about potential drawbacks of the Daresbury site. He says they have failed to do the "most basic thing that any planning consultant worth its salt would do - contact the local planning authority".

"It's foolish to say we are high risk [when] we have a sympathetic development agency," says Sue Smith, a union representative at Daresbury. "RAL does not even have potential [outline] planning permission."

The dispute over where Diamond should be sited has raised fears that choosing the Rutherford site would eventually lead to the closure of Daresbury and further deepen Britain's north-south divide.

Daresbury appears to have strong support from local government, local Members of Parliament, and Byers. The unions say they have a letter from an Oxfordshire councillor expressing concern at the prospect of economic "overheating" in the area around Rutherford and at problems of providing housing for the existing influx of workers into the region.
Natasha Loder 